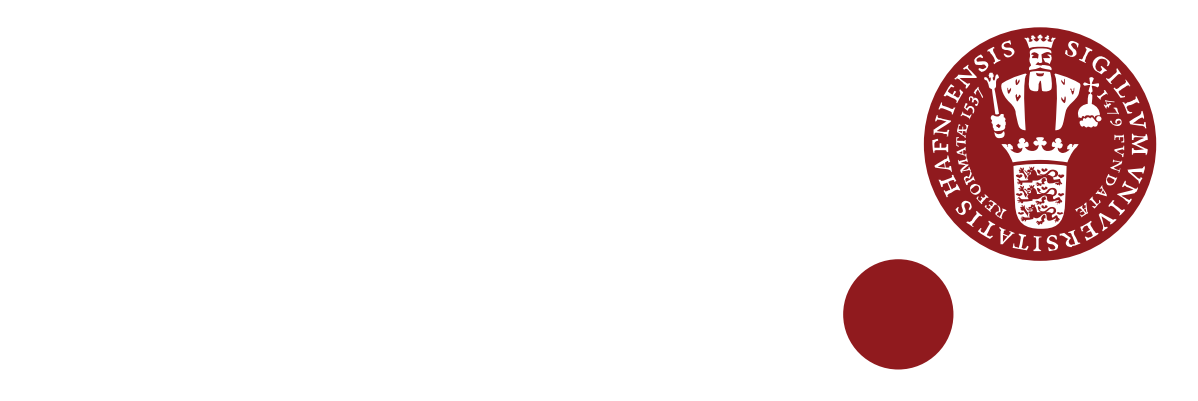

\title{
iCourts
}

iCourts Working Paper Series, no. 230, 2021

\section{Ideologies and imaginaries of legitimacy from the 1950s to today: trajectories of EU-Official discourses read against Rosanvallon's Democratic Legitimacy}

\section{Claudia Sternberg}

IMAGINE Paper No. 13

Conference EU Constitutional Imagination: Between Ideology and Utopia

Forthcoming in: Jan Komarek, ed., European constitutional imaginaries: Between ideology and utopia (Oxford, OUP).

iCourts - The Danish National Research Foundation's

Centre of Excellence for International Courts 


\begin{abstract}
:
This chapter traces changes in EU-official discourse around EU legitimacy since the 1950s, relating them to the trajectory described by Pierre Rosanvallon in Democratic Legitimacy (2011a). Accordingly, the legitimacy of modern democracies broke down in the 1980s owing to a loss of faith in its two main foundations in elections and bureaucracy. This gave rise to the emergence of alternative modes of legitimation, classed under the ideal types of impartiality, reflexivity, and proximity. This chapter plays Rosanvallon's analysis, which draws on national experiences, against the EU context. It finds important differences, in particular regarding the balance between electoral and bureaucratic legitimacy in the earlier years of integration - as well as significant similarities and interaction, manifested in a striking resonance between particular strands in EU-official legitimation strategies and Rosanvallon's ideal types. The ways in which they played out in the case of the EU point to dangers inherent to them; of highlighting proximity over actual influence and control; making democratic forms so complex and 'reflexive' that they become unintelligible, and unaccountable; or replicating bureaucratic thinking that obscures choices and judgments behind claims to independence and impartiality. What is more, the discursive history of contests over EU legitimacy illustrates a predisposition of Rosanvallon's account of democratic legitimacy towards "unpolitical democracy", rooted in its attempt to contain the threat of populism. His goal is to politicise the indirect institutions of impartiality, reflexivity and proximity rather than democratic procedures such as voting and majority rule, with the effect that deliberation is used strategically as an alternative to electoral and partisan democracy.
\end{abstract}

KEYWORDS: imaginaries, ideologies, democracy, legitimacy, discourse, European institutions, history, Pierre Rosanvallon

Claudia Sternberg, Principal Research Fellow at the UCL European Institute

E-mail: c.sternberg@ucl.ac.uk

IMAGINE has received funding from the European Research Council (ERC) under the European Union's Horizon 2020 research and innovation programme (grant agreement No 803163). 
iCoruts is funded by the Danish National Research Foundation Grant no. DNRF105.

iCourts - Centre of Excellence for International Courts - focuses on the ever-growing role of international courts, their place in a globalizing legal order, and their impact on politics and society at large. To understand these crucial and contemporary interplays of law, politics, and society, iCourts hosts a set of deeply integrated interdisciplinary research projects on the causes and consequences of the proliferation of international courts.

iCourts opened in March 2012. The centre is funded by a large grant from the Danish National Research Foundation (for the period 2012-18). 


\title{
Ideologies and imaginaries of legitimacy from the 1950s to today: trajectories of EU-Official discourses read against Rosanvallon's Democratic Legitimacy
}

\section{December 2020}

Claudia Sternberg, UCL European Institute, University College London, c.sternberg@ucl.ac.uk

Forthcoming in: Jan Komarek, ed., European constitutional imaginaries: Between ideology and utopia (Oxford, OUP).

\begin{abstract}
This chapter traces changes in EU-official discourse around EU legitimacy since the 1950s, relating them to the trajectory described by Pierre Rosanvallon in Democratic Legitimacy: Impartiality, Reflexivity, Proximity (2011). Accordingly, the legitimacy of modern democracies broke down in the 1980s owing to a loss of faith in its two main foundations in elections and bureaucracy. This gave rise to the emergence of alternative modes of legitimation, classed under the ideal types of impartiality, reflexivity, and proximity. This chapter plays Rosanvallon's analysis, which draws on national experiences, against the EU context.
\end{abstract}

It finds important differences, in particular regarding the balance between electoral and bureaucratic legitimacy in the earlier years of integration - as well as significant similarities and interaction, manifested in a striking resonance between particular strands in EUofficial legitimation strategies and Rosanvallon's ideal types. The ways in which they played out in the case of the EU point to dangers inherent to them; of highlighting proximity over actual influence and control; making democratic forms so complex and 'reflexive' that they become unintelligible, and unaccountable; or replicating bureaucratic thinking that obscures choices and judgments behind claims to independence and impartiality. What is more, the discursive history of contests over EU legitimacy illustrates a predisposition of Rosanvallon's account of democratic legitimacy towards "unpolitical democracy", rooted in its attempt to contain the threat of populism. His goal is to politicise the indirect institutions of impartiality, reflexivity and proximity rather than democratic procedures such as voting and majority rule, with the effect that deliberation is used strategically as an alternative to electoral and partisan democracy. 
A breakdown of legitimacy occurred in modern democracies in the 1980s, Pierre Rosanvallon sets out in Democratic Legitimacy: Impartiality, Reflexivity, Proximity. ${ }^{1}$ This saw people lose faith in both of the two traditional foundations of democratic legitimacy, the ballot box and the bureaucracy; neither parties and elected representatives nor public administrators could credibly claim to represent the general will or interest - the "generality" - of a people any longer. Focusing on changes in how democracies operate domestically, and particularly on examples from France and the US, Rosanvallon suggests that three ideal types of alternative modes of legitimation developed in response, namely the impartiality, reflexivity, and proximity of the book's subtitle. They represent three 'new, more indirect ways' of realizing social generality, and are embodied in corresponding indirect institutions. Impartiality achieved this through detachment from particularities and institutions that cannot be appropriated (such as authorities of surveillance or regulation). Reflexivity realises social generality by 'multiplying' the expressions of social sovereignty and making the subjects and forms of democracy more complex (for example, when a constitutional court determines the constitutionality of decisions made by the majority party). Proximity, finally, is associated with an 'art of government' that works through attention to, and recognition of, the particularity and multiplicity of all social situations. ${ }^{2}$ The institutions corresponding to this type of legitimacy include new forums of participatory and 'interactive' democracy such as citizen juries and issuebased conventions. ${ }^{3}$

In this chapter I relate Rosanvallon's analysis of democratic legitimacy at the national level to the EU level. He himself does not discuss legitimacy in European Union politics in much detail, or the effects that European integration has had on domestic politics. ${ }^{4}$ I explore how the decline and reconstruction of legitimacy that Rosanvallon describes for national democracies has related to the specific, and in many ways radically different, constellation of the European Union (EU) and European integration. To this end, I retrace changes and shifts in EU-official discourses constructing and contesting EU legitimacy from the 1950s to today, offering a longterm historical account of key modes of legitimation that shaped constructions and contestations of EU legitimacy over time, and of the challenges to which they were responding. I analyse the relevant discourses of the EU institutions as reflected in a diverse mix of sources including white papers, treaty preambles, council conclusions, press statements, official web sites and so on. Drawing eclectically on analyses presented previously, my reflections are based on non-quantitative interpretive textual analysis, by which I mean analysis that is concerned, empirically, with meaning and that works through close readings of texts identified, in iterative circles

\footnotetext{
1 Pierre Rosanvallon, Democratic Legitimacy: Impartiality, Reflexivity, Proximity (Princeton, Princeton University Press, 2011); see also his 'The Metamorphoses of Democratic Legitimacy: Impartiality, Reflexivity, Proximity' (2011) 18(2) Constellations 114-123.

2 Rosanvallon, n.1 Democratic Legitimacy, 117.

${ }^{3}$ Rosanvallon, n.1 Democratic Legitimacy, 203-18.

${ }^{4}$ His lecture entitled 'The Transformation of Democracy and the Future of Europe', delivered in 2001, mainly discussed changes he observed nationally, suggesting that the same dynamics that transformed domestic legitimacy dynamics may have affected politics at the EU level. In: S. Moyn (Ed.), Democracy Past and Future. (New York: Columbia University Press 2006, 218-34),
} 
of reading large textual corpuses, as exemplary of discursive positions, patterns, or shifts relevant to the questions under study. ${ }^{5}$

Did the EU's specific legitimacy challenges and the related shifts in legitimation strategies, discourses, and practices partake of the same underlying transformations of modern political life as national democracies, or did they play to a different tune? Did the EU in fact function as a 'laboratory', a 'space of experimentation' with new forms of democracy, feeding back, perhaps, into the legitimacy revolution in the national democracies ${ }^{6}$ Or, put more cynically, did the emerging alternative modes of legitimation the emergence of which Rosanvallon traces serve as a playbook for masterminds of discursive rationalisations, directive utopias, and pragmatic critiques of EU legitimacy?

By focusing in on imaginations of the EU's legitimacy more broadly, including but not limited to legitimacy arising from constitutional elements, this chapter places the constitutional imaginations under investigation in this book in their wider context. Casting its net even wider, the rival visions of legitimate authority and power that compete for enactment, institutionalisation, and constitutionalisation in the EU's struggle for legitimacy-grounded in creative collective imagination-are situated in embedding 'social imaginaries' through which 'people imagine their social existence, how they fit together with others, how things go on between them and their fellows, the expectations that are normally met, and the deeper normative notions and images that underlie these expectations'. It is these imaginaries that constitute 'that common understanding that makes possible common practices and a widely shared sense of legitimacy'. 7

In common with the book's overall approach, I treat imaginations of EU legitimacy as ideologies, as in clusters of ideas that 'provide directives, even plans, of action for public policy-making in an endeavour to uphold, justify, change or criticize the social and political arrangements of a state or other political community'. ${ }^{8}$ Like political philosophies, such ideologies are constellations of concepts. But in contrast to the former, they are intended to orient and inform political praxis, and they are not reducible to a specific author or set of authors, but rather characteristic forms of "group thinking". ${ }^{9}$ I approach EU legitimacy pragmatically in that I investigate contests over normative beliefs and ideas through the lens of standards to which actors commit themselves, both in their political and other language and in their attempts to cope with practical problems and challenges.

\footnotetext{
${ }^{5}$ Claudia Sternberg, The Struggle for EU Legitimacy: Public Contestation, 1950s-2005 (Basingstoke: Palgrave Macmillan 2013); id. 'Political legitimacy between democracy and effectiveness: Trade-offs, interdependencies, and discursive constructions by the EU institutions' (2015) 7(04) European Political Science Review, 615-638; Claudia Sternberg, Gartzou-Katsouyanni, K., \& Nicolaidis, K. The Greco-German Affair in the Euro Crisis: Mutual Recognition Lost? (London: Palgrave Pivot 2018); see Dvora Yanow \& Peregrine Schwartz-Shea, Interpretation and Method. Empirical Research Methods and the Interpretive Turn (Armonk, N.Y.: M.E. Sharpe, 2006).
}

${ }^{6}$ Pierre Rosanvallon, n. 4, 232-4.

${ }^{7}$ Charles Taylor, Modern Social Imaginaries (Durham, NC: Duke University Press, 2003), 23; see Yaron Ezrahi, Imagined Democracies: Necessary Political Fictions (Cambridge: CUP 2012).

${ }^{8}$ Michael Freeden, 'Ideology, Political Theory and Political Philosophy'. In Handbook of Political Theory (London: Sage 2004, 3-17), 6.

${ }^{9}$ Michael Freeden, Ideologies and Political Theory: A Conceptual Approach (Oxford: OUP 1998). 
In addition to this more analytical, neutral understanding, moreover, competing visions of political legitimacy are ideologies in the more critical sense of concealing the negative impact and the inherent contradictions of their constitutive ideas. They are 'necessary fictions' that people rely on them when making sense of their experience of collective life-and that make political rule possible in the face of inescapable contradictions, clashes, and compromises involved wherever ideals are pursued. ${ }^{10}$ We can either be cynics about this, or we have to decide not to see certain things. Our imaginations of political legitimacy are ideologies not least in that they use meaning 'to establish and sustain relations of domination', not least by favouring certain plans of action over others, and 'mak[ing] the products of human activity appear natural and fixed, excluding any possibility to change them'. ${ }^{11}$ This chapter explores ways in which the discourses and modes of legitimating the EU and European integration discussed rest on fictions that conceal contradictions, negative impacts, and power relations, and how these fictions contributed to their respective rise and decline over time.

\section{The dual foundation of democratic legitimacy: elections and bureaucracy}

Rosanvallon's 'dual foundation' of modern democratic legitimacy, from the turn of $20^{\text {th }}$ century, on elections on one hand and public administration on the other is a case in point for how the underlying 'foundational fictions' already mapped out the collapse of perceived legitimacy in modern democracy of the $1980 \mathrm{~s} .{ }^{12}$

$\mathrm{He}$ is particularly critical of electoral democracy, which in his reading always rested on a 'necessary but insufficiently acknowledged' fiction that 'assimilated the majority to the unanimous whole' and the related idea of a general will; that a majority could stand for the people as a whole, and a fictitious "people" symbolically for the whole of society. ${ }^{13}$ The idea that the interests of the whole of society could somehow be expressed through a majoritarian electoral system, Rosanvallon proposes, 'lost all credibility' as early as 1890 to 1920 ; as legislatures and party systems emerged, and universal suffrage spread, elections 'ceased to be a kind of sacrament marking the kind of social unity that prevailed in the moment that a people achieved autonomy', becoming 'instead a means of expressing social division'. ${ }^{14}$ He supports this view by describing how parliaments and parties came to be seen by many as prone to incompetence, corruption and, above, all capture, establishing a 'system of bargaining in thrall to special interests' and the 'rivalries of personalities and clans'making antiparliamentarism a powerful force. ${ }^{15}$

In this light, he continues, democratic regimes searched for 'more realistic and objective ways' of grounding their democratic legitimacy, looking to 'the bureaucratic machine' as a better force to achieve social generality and realise the general interest (which had replaced the 'common good' as an aspiration. Rooted in a cultural background of early $20^{\text {th }}$-century theories of scientific management and

\footnotetext{
10 Ezrahi, n. 7.

11 John B. Thompson, Ideology and Modern Culture: Critical Social Theory in the Era of Mass Communication (Cambridge: Polity Press, 1994), 56; see Jan Komarek's chapter in this volume.

12 Rosanvallon, Democratic Legitimacy, 3, 15-72; Metamorphoses, 114-6.

13 Rosanvallon, Democratic Legitimacy, 2, 13.

14 Rosanvallon, Democratic Legitimacy, 2-3, 29-30.

15 Rosanvallon, Democratic Legitimacy, 2-3, 36.
} 
mystiques of rationality, this mode of legitimation involved rethinking the concept of political legitimacy in ways where public power was no longer legitimated (solely) by its origin but by the 'services it renders'. ${ }^{16}$ The idea took hold of an independent, objective power, identified with the general interest. Across post-WWII Europe, civil servants 'dedicated to an agenda of modernization' portrayed themselves 'as the representatives of a new type of legitimacy based on efficiency and competence', rationality and disinterestedness. ${ }^{17}$ Bureaucracy, Rosanvallon suggests, came to be seen as a counterweight to the shortcomings of electoral democracy, a 'means of combating parliamentarism and the party state' (here, Rosanvallon refers to Carl Schmitt), as well as the associated incompetence. Crucially, it was situated outside the sphere of politics and the temporality of the electoral cycle, minimising 'the inconveniences of elections', while being kept virtuous and efficient by parliamentary control. ${ }^{18}$

Before long, however, bureaucracy, too, succumbed to its own contradictions and limitations as a source of legitimacy, compounded not least by 'neoliberal rhetoric', which damaged the credibility of the state by proposing the 'market as the new regulator of collective well-being'. ${ }^{19}$ As the efficient provision of services by the state faltered, around the 1970s, administrative power lost both its moral legitimacy, based on the recognition of its disinterestedness, and its professional legitimacy. ${ }^{20}$

Economic theory called attention to the informational dysfunctions of state administration and, more broadly, the 'the aura of rationality that had once legitimated the power of civil servants had dissipated'. ${ }^{21}$

The collapse of national democratic legitimacy in the 1980s, for Rosanvallon, then, resulted from the contradictions and fictions inherent to both the bureaucratic and the electoral modes of democratic legitimation. How crisis-proof was the legitimacy of the European Communities in comparison?

\section{European integration and the post-war constitutionalist ethos}

To begin, were the early European Communities (ECs) less encumbered by the need to claim electoral-majoritarian legitimacy, and therefore possibly less subject to its inherent problems and its subsequent crisis? According to an academic argument, 'non-majoritarian standards of legitimacy should be sufficient to justify the delegation of necessary powers' to the European level, given the particular functions that its essentially 'regulatory system' performed. ${ }^{22}$ This reasoning extended far into

\footnotetext{
16 Rosanvallon, Democratic Legitimacy, 2-3, 39, 45. In this chapter, I use the term "bureaucracy" to refer to both "bureaucracy" in its classical sense denoting the state administration of the ideal-typical liberal state of the $19^{\text {th }}$ and the beginning of the $20^{\text {th }}$ centuries, and "technocracy" or the early-to-mid$20^{\text {th }}$ century development of the welfare state and industrial management. See Jennifer M. Hudson, The Bureaucratic Mentality in Democratic Theory and Contemporary Democracy (Columbia University, PhD Thesis, 2016), 14ff.; Jürgen Habermas, 'Technology and Science as "Ideology"', in Toward a Rational Society, trans. Jeremy J. Shapiro (Boston: Beacon Press, 2014).

17 Rosanvallon, Democratic Legitimacy, 50-3.

18 Rosanvallon, Democratic Legitimacy, 48-50.

19 Rosanvallon, Democratic Legitimacy, 4.

20 Rosanvallon, Democratic Legitimacy, 68.

21 Rosanvallon, Democratic Legitimacy, 67.

22 For example, Giandomenico Majone, 'Europe's Democratic Deficit: The Question of Standards' European Law Journal (1998) 4, 5-28.
} 
the public and political spheres, well into the 1990s and 2000s. Indeed, the ubiquitous motif in early defences of supranational integration was that integration was strictly limited to specific sectors and politic tasks that were particularly suited to the technocratic, bureaucratic, elitist, and administrative rationalities which underlay much of the Communities' institutional setup, actions, and rhetoric. ${ }^{23}$

In the early days of integration many deemed electoral democracy not particularly suited in any case, to legitimating the nascent European construct. ${ }^{24}$ Neither the Paris nor Rome Treaty even contained the word 'democracy' (or 'democratic'); nor did the 1950 Schuman Declaration. Existing rival blueprints that envisioned European unity as resulting, say, from the impetus of a directly elected European parliament were up against important odds. ${ }^{25}$ Informed by the experience of authoritarianism, social, intellectual, and political imaginaries of political legitimacy during the early years of integration exposed a deep-seated distrust in unrestricted mass democracy.; 'whether the democratic nature of the regimes of post-war Western Europe rendered them legitimate in the eyes of their populations' was a complex question. ${ }^{26}$ Only gradually, over the course of the 15 years following the Second World War, had democracy emerged as the key element of political legitimacy in post-war Western Europe. ${ }^{27}$ If there was a crisis of electoral democracy as a source of political legitimacy in the 1980s, it was certainly not the first existential crisis of majoritarianism.

European integration was part and parcel of Europe's particular new 'constitutionalist ethos' after World War II, marked not least by an integral suspicion of popular sovereignty. ${ }^{28}$ Western Europe's post-war 'constitutional settlement' was defined by the perceived imperative to constrain peoples and check the dangers of potentially totalitarian democracy. Countermajoritarian safeguards including constitutional courts and provisions for 'militant democracy' were created and eventually broadly accepted. ${ }^{29}$ The idea of unrestricted parliamentary supremacy ceased to be seen as legitimate outside Britain, and parliaments were deliberately weakened, not least in their self-destructive ability to delegate power, leading to an important role of the national executives. Besides, the post-war decades were the age of the everexpanding welfare and regulatory state, and many of its functions were delegated to administrative agencies, subject to strong judicial and administrative-but no longer

\footnotetext{
${ }^{23}$ See Sternberg, n. 4 Struggle, 235, fn. 10; Claudia Sternberg, 'Democracy Narratives', in Mathieu Segers et al., eds., The Cambridge History of the European Union (Cambridge: CUP forthcoming).

${ }^{24}$ Michael Burgess, Federalism and European Union: The Building of Europe, 1950-2000 (London: Routledge 2000), 31-6.

${ }^{25}$ See Michael Burgess, Federalism and European Union: Political Ideas, Influences, and Strategies in the European community, 1972-1987 (London, New York: Routledge 1989), 31-6.
}

${ }^{26}$ Martin Conway \& Peter Romijn, 'Introduction to Theme Issue: Political Legitimacy in Mid-Twentieth Century Europe' (2004) 13 Contemporary European History 377-388 (380).

${ }^{27}$ Martin Conway \& Volker Depkat, 'Towards a European History of the Discourse of Democracy: Discussing Democracy in Western Europe 1945-60', In Martin Conway \& Kiran Klaus Patel, ed. Europeanization in the Twentieth Century: Historical Approaches (Basingstoke and New York: Palgrave Macmillan 2010, 132-156).

${ }^{28}$ Peter L. Lindseth, Power and Legitimacy: Reconciling Europe and the Nation-State, (Oxford: Oxford University Press, 2010).

29 Jan-Werner Müller, Contesting democracy: Political ideas in twentieth-century Europe (New Haven: Yale University Press, 2013), 146-50. 
parliamentary-oversight. ${ }^{30}$ The European states gave powers not only to unelected domestic institutions, but also to supranational bodies under the close supervision of national governments (rather than parliaments). The motivation was to "lock in" liberal-democratic arrangements, prevent a backsliding towards authoritarianism, and to make another European war 'not only unthinkable, but materially impossible'. ${ }^{31}$

\section{Bureaucratic champions of peace, prosperity and progress}

In this sense, European integration in its first decades was very much the embodiment of Rosanvallon's other, non-electoral, bureaucratic type of legitimacy. This type of legitimacy arose from being "helpful" in serving people's interests or the common good. Against the experience of Europe's history of bloodshed, and the trauma and perceived ongoing threat of totalitarianism, European integration was cast as "indispensable"; a matter of no alternative, even of survival. ${ }^{32}$ Some of the discourses celebrating integration had a moralising undertone, a sense of overcoming past horrors resulting 'from within ourselves', which often combined with an emphasis on hope, agency, and determination in bringing about the 'greatest voluntary and purposeful transformation in the history of Europe'. ${ }^{33}$ The central substantive promises behind integration, throughout the 1950s and 1960s, were peace and prosperity, or "economic progress" and "improved living conditions". ${ }^{34}$ Foundational legitimation discourses here linked peace, prosperity and integration to each other; one was not to be had without the other ${ }^{35} \mathrm{~A}$ ubiquitous anti-totalitarian imperative, and the presence of a totalitarian alternative in Central and Easter Europe, helped to downplay not only any existence of economic ideological choices, but also even the possibility of a different political system and ideology of legitimacy-all of which changed in the 1970 s. ${ }^{36}$ For a certain initial period of grace though the road to the universally shared aspirations of higher standards of living, as well as of personal and political freedom, could with relative plausibility be framed as passing exclusively through European economic integration, in its emerging ideological and institutional-constitutional setup.

The Communities' bureaucratic legitimacy was implanted in a widely shared belief in government intervention and an active state, particularly strong in France but characteristic of Western Europe more broadly, whereby a 'caring state' was generally conceived to be the "most suitable means for the promotion of "the good" of both the individual and the collective'. ${ }^{37}$ Early legitimation discourses hence represented the Communities as the apex and 'the natural extension of the processes of social and political rationalization already well advanced in the

\footnotetext{
30 Müller, n. 29, 148-9; Lindseth, n. 28.

311950 Schuman Declaration; see Lindseth, n. 28, 104; Müller, n. 29, 149.

32 Sternberg, n. 4 Struggle, 16-22.

33 Respectively, Italian Foreign Minister Gaetano Martino and Belgian Foreign Minister Paul-Henri Spaak in their addresses upon signing the Rome Treaties, Rome, 25 March 1957 (www.cvce.eu, accessed 14/05/2019).

34 See for example EEC Treaty Preamble, ECSC Treaty Article 2, or the 1955 Messina Declaration.

35 Sternberg, n. 4 Struggle, 21-2.

36 Müller, n. 29.

37 David Held, Models of Democracy, (Stanford: Stanford University Press 2006), 186.
} 
historical evolution of modern states'. ${ }^{38}$ In this imaginary, good and legitimate government was government that was effective in solving concrete problems, professional, impartial, predictable as in following clear procedures. ${ }^{39}$ This bureaucratic, sober nature of the integration project was central to helping the Europeans to leave behind the divisive passions, impulses and 'excited demands' associated with 'politics', and to achieve social and economic progress, and peace. ${ }^{40}$ The vision was that of a Europe united by a bureaucracy, and at is centre, the Commission's professional civil service recruited through merit-based competitive exams.

\section{European generality and the "European common good"}

Bureaucratic legitimacy, Rosanvallon proposes, flows from the realisation of a new, 'substantive vision of the general interest'. ${ }^{41}$ Now, any substantial or output-based legitimacy claim requires some substantive conception of, or way of formulating, the guiding goals of performance outputs. ${ }^{42}$ Yet, if the point of bureaucracy, as Rosanvallon points out, was to offer an alternative to 'discredited' party politics, ${ }^{43}$ the specific conception of the general interest that ought to be translated into public policy would not necessarily be constructed through democratic procedures of parliamentary deliberation or electoral competition. Rather, a substantive vision of its nature was part of many discourses defending and defining the legitimacy of the early European Communities, which were engaged not only in establishing there was such a thing as a European "common good" or "common interest" (often used interchangeably), but also in projecting substantive ideas as to its precise natureand that this was (or could be) furthered by European integration. ${ }^{44}$ These substantive ideas typically started from the growing and inescapable, interdependence of West-European nation-states under conditions of Cold War international relations, modern technology, and mass production; and moved on to praise the interlocking, by deliberate design, of the interests of the European peoples into a common destiny, ${ }^{45}$ a 'grand design for Europe' commonly framed as a win-win enterprise and, crucially, 'not a game in which one side wins and the other loses'. ${ }^{46}$

The Commission had a particular interest in entrenching the image of a European common good, and its specific visions of what it consisted in. It positioned itself quickly as 'as the repository of the European General Will', and the guardian of the treaties it administered, as 'the basic European consensus for progress, peace, and federation'-in other words, the basic consensus on the very substance of the

\footnotetext{
38 Lene Hansen \& Michael C. Williams, "The Myths of Europe: Legitimacy, Community and the "Crisis" of the EU' (1999). Journal of Common Market Studies 37, 233-249 (243).

39 William Walters \& Jens Henrik Haahr, Governing Europe. Discourse, governmentality and European integration (London and New York: Routledge, 2005), 21-41.

40 Ernst B. Haas, 'Technocracy, Pluralism and the New Europe. International Regionalism', in Joseph. S. Nye, ed., International Regionalism (Boston, MA, Little Brown 1968, 149-176), 159.

41 Rosanvallon, n.1 Democratic Legitimacy, 50-3.

42 Sternberg, n. 4 Trade-Offs.

43 Rosanvallon, n.1 Democratic Legitimacy, 50-3.

44 Sternberg, n. 4 Struggle, $20 \mathrm{ff}$.

45 For example, ECSC Treaty, Preamble.

46 'Une Europe empirique’, Le Monde 26 March 1957, p. 1.
} 
European common good. ${ }^{47}$ Whereas others saw the European common interest as best served by intergovernmental cooperation or different versions of federalism, ${ }^{48}$ Commission discourse and action presented it as most effectively pursued through action in the Community framework. If the guiding purpose of the integration project could indeed be imagined as subject to an overall permissive consensus, bureaucrats could be argued to be best placed to deliver on this promise. The Commission fashioned itself as the Communities' "champion of generality", its 'initiator, planner and mediator for the common good', providing independent, impartial, and technically sound proposals. Its role was to give concrete meaning the supposed European general will, interpreting the general interest and, in this, going far beyond mere compromise or lowest common denominators. ${ }^{49}$

Such substantive projections of the general European interest and a supposed consensus on the guiding goals and purpose of integration, embedded in the discourse of no alternatives, worked hand in hand with the Communities' technocratic approach, whereby 'government action follow[ed] the advice of experts'. ${ }^{50}$ Together, they de-politicised innately and undeniably political institutional and policy choices, taking many of them out of the more politicised realms of political will formation grounded in the electoral process and wider public debate. ${ }^{51}$

\section{Electoral legitimacy after all?}

At the same time, counteracting the Communities' technocratic modus operandi and the prevalent use of the bureaucratic mode of legitimation, were deliberate rhetorical as well as political and institution-building efforts more firmly to anchor the integration process in the electoral legitimacy domain.

One can be subsumed under the heading of intergovernmentalism. The electoral legitimacy and accountability of nationally elected representatives, and an association of 'the political' with intergovernmentalism and domestic political processes, were important tropes in justifications of the Communities' strong intergovernmental elements. ${ }^{52}$ Charles de Gaulle staked out in the mid-1960s that 'nothing which is important [ ... ] should be decided and, even more, applied, by anyone but the responsible public authorities in the six States, that is, the governments controlled by the parliaments'. ${ }^{53}$ Beyond French Presidential rhetoric, the 'establishment of national-executive leadership over the integration process' could be mapped from the creation of the Council of Ministers in the 1951 ECSC Treaty, over the strengthening of its institutional role in the 1957 EEC Treaty, to the creation of the European Council in 1974. Combined with a dense bureaucracy of

\footnotetext{
47 Haas, n. 40, 456.

48 Ibid.; see Sternberg, n. 4 Struggle, 46-67.

49 Here Commission, 'Report of the Working Party examining the problem of the enlargement of the powers of the European Parliament. "Vedel Report”', BEC Supplement 4/72 (1972); see Sternberg, n. 4 Struggle, 29.

50 Featherstone, n. 56, 150, 154

51 Sternberg, n. 4 Struggle, 14-44; see Luuk van Middelaar, Alarums and excursions (Newcastle: Agenda Publishing, 2019), 228.

52 Sternberg, n. 4 Struggle, 63.

53 Charles de Gaulle, Press conference 09 September 1965, http://aei.pitt.edu/5356/ [accessed 17/07/2019].
} 
nationally dominated committees staffed by national civil servants to oversee the Commission's implementation of delegated acts, this effectively 'marginalised the Commission as an autonomous technocratic policy maker'. ${ }^{54}$ It also de-legitimated it in this role, and instead rooted electoral legitimacy firmly on the discursive map of how one could credibly talk about Community legitimacy.

Electoral legitimacy furthermore came into play prominently as regarded the 'lawful legislative enactment' or 'loi cadre' for the delegation of tasks to the EU as a 'regulatory state' and its semi-autonomous authorities such as the European Court of Justice, the EU regulatory and administrative agencies, and later the European Central Bank. ${ }^{55}$ There was a sequencing logic to the normative-legal principle of delegation, whereby legislative enactment would be followed by a change to a bureaucratic (or constitutional) register, 'on the basis of governments giving a remit to experts and for them to get on with it', as UK Prime Minister Edward Heath commented in a 1972 BBC interview. ${ }^{56}$ It was first and foremost domestic democratic and constitutional procedures that democratically legitimated delegation, but a role in fixing the standards 'within which the Community can act' would also be claimed for the European Parliament. ${ }^{57}$

The campaign for direct elections to the European Parliament took speed in the 1960s (the first taking place in 1979). Advocacy of a strong and elected EP took on early de-politicisation and technocratic discourses and techniques, promising nothing less than the end of 'the reign of the technocrats'. ${ }^{58} \mathrm{~A}$ common case made turned on the 'eminently political' nature of what the Communities were doing, which clashed with their reliance on efficient governance by experts or technocrats largely protected from popular interference. ${ }^{59}$ The 'daily experience of the Communities in all sectors', and the empty chair crisis of the 1960s, had made clear that not everyone agreed what the Communities should be doing and how, and that some way of legitimating choices of objectives as well as ways of pursuing them was called for; since 'free elections' were the only known means for 'expressing the will of the people,' only a strong and directly elected EP could produce and legitimate 'act[s] of political will' that were 'the only way out of dead ends' once 'the experts' resources are exhausted'. ${ }^{60}$

Perhaps the most important and vocal argument, however, put forward in favour of European elections played on what Rosanvallon refers to as the lost function of elections as a 'kind of sacrament marking [...] social unity'. ${ }^{61}$ This framed EP

\footnotetext{
54 Lindseth, n. 26, 91, 100.

55 Lindseth, n. 26, 2, 104; see Sternberg, n. 4 Struggle, 38-9 for source references.

${ }^{56}$ Kevin Featherstone, 'Jean Monnet and the 'Democratic Deficit' in the European Union', (1994) 32 Journal of Common Market Studies, 149-170 (160).

${ }^{57}$ E.g. Commission, n. 49 Vedel Report, 17.

58 Frankfurter Allgemeine Zeitung 14 July 1976.

${ }^{59}$ EPA, « Rapport fait au nom la commission des affairs politiques et des questions institutionnelles sur l'élection de l'Assemblée parlementaire européenne au suffrage universel direct. Rapporteurs Emilio Battista, Fernand Dehousse, Maurice Faure, W.J. Schuijt, and Ludwig Metzger », EP Session Documents 1960-61, 30 April 1960, Document 22, particularly pp. 16-7.

$60 \mathrm{lbid}$.

${ }^{61}$ Rosanvallon, n.1 Democratic Legitimacy, 29-30; see above.
} 
elections as a sort of forge for demos-hood; a way to associate the peoples to the building of Europe and to each other in a European Leviathan, ${ }^{62}$ as possessing the diffuse power of inciting an emotive, unifying response on the part of the electorate, making citizens 'feel more concerned by the enterprise' and 'want to live together'. ${ }^{63}$ Echoing $19^{\text {th }}$ century advocacy of universal suffrage on the grounds of its substantive consequences for the adoption of "correct policy", 64 EP elections were canvassed also on the basis that they would allow for the EP to act as a "motor for integration". Some of the advocacy for European elections reverberated, further, with Gaullist and older notions of 'elections of recognition', or of acclamatory as opposed to partisan elections; of votes that served to express and incite popular endorsement, and to express social unity rather than divided interests. ${ }^{65}$

Surprisingly or not, neither the introduction of European elections in 1979 nor the concurrent and subsequent gradual expansion of the EP's powers had quite these effects on popular feelings, yielding instead disappointing and famously falling turnouts in the years and decades to come. Was this because EC electoral legitimacy was falling victim to a much broader process on the way across modern democracies?

\section{Democratic legitimacy collapsing?}

What Rosanvallon calls the 'de-sacralisation' of elections involved a blurring of the lines of party confrontation and weakened party ties. Whereas in "the "golden age" of the representative system', elections had bestowed an 'incontestable mandate' and legitimated future policies a priori, their function was now 'whittled down' to 'simply the process by which we designate those who govern'. ${ }^{66}$ EP elections, of course, to this day do not legitimate policies based on the claim that future policies were implicit in clearly understood, predictable, and sufficiently different electoral choices between disciplined parties and well-defined programmes, and do not even have a very strong claim to designate those who govern. ${ }^{67}$ Perhaps expectations had always been lower in the case of EP elections, and hence their fall as a source of legitimacy was from a lesser height than for the national context. If the electoral legitimacy of the EC was affected indirectly, in that it depended on the legitimacy of its memberstates' delegating and controlling electoral-democratic systems, the desacralisation of elections everywhere may effectively have taken some pressure off the EP and EP elections as they continued to fail in magically boosting integration and the Community's social and normative legitimacy (precisely these diffuse, symbolic and unifying powers of electoral democracy would have been hardest-hit by the desacralisation of elections).

The more existential threat to Community legitimacy was that, by the 1970s, its bureaucratic or output dimension came under increasing pressure as well, just as for the member-states. Following the oil shocks and ensuing financial and economic

\footnotetext{
62 EPA n. 57, 16.

63 Le Monde 12 June 1979.

64 Rosanvallon, n.1 Democratic Legitimacy, 30-1.

65 Rosanvallon, n.1 Democratic Legitimacy, 18-20, 68.

66 Rosanvallon, n.1 Democratic Legitimacy, 4, 69-79.

67 Peter Mair \& Jacques Thomassen, 'Political Representation and Government in the European Union', (2010) Journal of European Public Policy 17, 20-35.
} 
crises, the economies across Europe were in recession. East-West relations were tense again. Delivery on the promise of peace and prosperity was faltering.

'Overloaded government' and the 'legitimation crisis' of the capitalist welfare state were much debated in the public spheres across Europe, ${ }^{68}$ the administrative system seen to fail in reconciling the pressures coming from the economic system, ${ }^{69}$ and economic ideologies now fiercely debated. ${ }^{70}$ All this manifested itself in as a loss of confidence in governmental as well as Community institutions, including in the impartiality and rationality of the bureaucracy. "Eurocracy" became a dominant emblem in depictions of European integration in the 1970s, the fiction of the EU bureaucracy and its policies being apolitical, technical, or politically neutral unravelling. ${ }^{71}$ How dire the situation had become by the late 1970 s and early 1980 s was encapsulated in an Economist cover in March 1980 depicting the Community's gravestone.

Revolutionising legitimating ideologies, decentering democracy?

How did official rhetoric try to revitalise the seemingly moribund integration project, to maintain and rebuild its legitimacy? If the Communities as a technocracy in essence suffered disproportionately from the decline of bureaucratic legitimacy, and if its electoral legitimacy had always been one part delegated and one part problematic, was this used as an opening for experimenting with alternative modes of legitimation, more creatively and earlier perhaps than for national democracies? In Rosanvallon's book, the weakening of electoral and bureaucratic legitimacy ushered in a 'veritable revolution in the conception of legitimacy', a 'decentering of democracy' whereby '[d]emocratic politics became something more than merely electing representatives'. ${ }^{72}$ A comparable stretching of what democracy might mean can be observed for EU-official discourses, in dialogue with developments in the memberstates. There is a striking resonance between the involved legitimation strategies and Rosanvallon's alternative modes of legitimation of particularity, reflexivity, and impartiality.

\section{Proximity, the People's Europe, and Openness and Transparency}

In Rosanvallon's ideal type of proximity, legitimacy springs from the state or authority's ability to respond to the particular and immediate concerns of individuals, delving into the irreducible diversity and complexity of society by 'forgetting no one and attending to everyone's problems'. ${ }^{73}$ Such proximity or "closeness" to the citizens has been a key trope in EU-official legitimating rhetoric ever since the late 1970 s and the 1980s. There was a distinct turn, from the earlier emphasis on the top down delivery of what was right and good for Europe, to a new focus on the European citizens and their particular needs, sensitivities, and expectations: 'We must listen to our people. What do the Europeans want? What do they expect from a

\footnotetext{
68 Held n. 35, 190-6; Jürgen Habermas, Legitimation Crisis (Boston: Beacon 1973).

69 Habermas, n. 66.

70 Müller, n. 27.

71 Sternberg, n. 4 Struggle, 69-71; Tsakatika, n. 120; Featherstone, n. 56.

72 Rosanvallon, n.1 Democratic Legitimacy, 7.

73 Rosanvallon, n.1 Metamorphoses, 117.
} 
united Europe?'74 This turn was firmly anchored in the 1980s in the EU institutions' concerted campaign and system of policies designed to re-imagine the European Communities as a "People's Europe" or "Citizen's Europe", used synonymously. ${ }^{75}$

Defined in essence as a Europe "close to its citizens", the People's Europe was to reach deeply into the life worlds of individual citizens in all their diversity and complexity. Making Europe relevant to citizens personally, giving it a 'human interest' has been a central trope in EU-official legitimation technologies and discourses ever since. ${ }^{76}$ The People's Europe was to be present and tangible in people's everyday life in the forms of material benefits connected for instance to freedom of movement such as Erasmus stipends or cheap petrol across the border, and symbols such as European flags or the anthem. Cultural policies, moreover, were geared to make people associate Europe with culture, and this culture intimately with themselves in their self-understandings. ${ }^{77}$ It was a conscious effort to balance out the negative images of the 'trader's Europe', excessively focused on the market and addressing citizens mainly as "market citizens", as well as the 'technocrat's Europe', remote from the people and determined by expert rationalities, ${ }^{78}$ the People's Europe addressed people holistically, as socially and culturally embedded human beings in the multiple threads weaving them into the social and cultural fabric of Europe.

At the same time, in its focus on the particular citizen and her experiences, the People's Europe campaign also went beyond their concurrent re-creation as political (eventually "Union") citizens with protection as well as political rights specific to the European Community-part of flanking efforts to strengthen the electoral-legitimacy register for the EC context. In this, EU legitimation strategies were attuned to what Rosanvallon refers to as the "the advent of the individual" or the "age of particularity", as regarded not only modes of production and consumption under post-Fordist capitalism, but also conceptions of the role of the state and citizen expectations in politics given not least postmodern perceptions of the future in terms of risk rather than progress. In a world where social bonds and identities were no longer defined by generic categories or relations of production, he suggests, a people could no longer 'be apprehended as a homogenous mass' where the interests of the greater number could be identified with the interest of the majority and of the people as a whole. In this world, 'winning an electoral majority is no longer enough to legitimate a government', so modes of legitimation alternative to electoral democracy gained ground. ${ }^{79}$

${ }^{74}$ Commission, 'European Union. Report by Mr. Leo Tindemans, Prime Minister of Belgium, to the European Council, 27 December 1975' (1976) BEC Supplement 1/76, p. 11-35 (here 11).

75 See, for example, Commission, 'Reports from the Ad Hoc Committee on a People's Europe, Brussels, chaired by Pietro Adonnino, 25 and 26 June 1985, and 29 and 30 March 1985', BEEC Supplement 7/85, p. 2-33; Commission, 'A People's Europe. Communication from the Commission to the European Parliament (7 July 1988)' COM 88 331/final, Bulletin of the European Communities Supplement 2; Council. 'Conclusions of the Fontainebleau European Council (25 and 26 June 1984)', Bulletin of the European Communities June 1984, 11-12; see Sternberg, n. 4 Struggle, 76-102.

${ }^{76}$ For a more recent re-formulation, see Commission, White Paper on a European Communication Policy COM(2006) 35 final, (01/02/2006).

77 Sternberg, n. 4 Struggle, 89-100; see Cris Shore, Building Europe. The Cultural Politics of European Integration (London: Routledge 2000).

78 Commission, n. 74 People's Europe, 1.

${ }^{79}$ Rosanvallon, n.1 Democratic Legitimacy, 60-5, 69-70. 
The focus in discourses arounds the People's Europe on particular citizen experiences took up these sensitivities, readily perhaps given the particular difficulties in the EU case in claiming electoral legitimacy given the specific challenges of its representative system. The "democratic deficit" critique firmly established itself in the European public and political debates around the time of the difficult ratification of the Maastricht Treaty in the early 1990. So did the question of whether democracy was possible at all on a European scale given the lack of a European demos; in Germany, for example, the no-demos critique spilled over from the legal into the wider public debate around that time, and in France an important discourse confined the practice of democracy and citizenship, or simply "the political", to the nation-state, on the grounds that there was no European nation that could have a volonté générale. ${ }^{80}$

A democratic imaginary transcending the requirement of a homogenous statepeople, in which a 'people' existed 'as a narrative, a collection of stories, rather than a fixed voting bloc', ${ }^{81}$ was attractive under these discursive conditions, offering an alternative to the demos-building techniques that were a dominant complementary approach in EU-official legitimation strategies from early identity-building attempts in the 1970s over the project of the 2000s of an EU constitution complete with constitutional patriotism, which were always at least ambitious. ${ }^{82} \mathrm{~A}$ people conceived of as a collection of stories and particularities also went some way towards a response to the crumbling of projections of a consensual European common good or the possibility of a European social generality, all of which could not undo or even sustainably paper over the fact of fundamental conflicts of interests, values and identity among and within the member-state demoi. Appealing directly to citizens in their daily life and immediate life world was a way of bypassing the problematic and tenuous level of a somehow coherent body politic. In the case of the EU, the legitimation mode of particularity further expressed itself in a focus, in the paradigms of EU "governance" and participatory democracy (discussed in the next section, under the rubric of reflexivity), on subsets of citizens or 'a series of minority conditions, which are in turn 'diffracted expressions of social totality'. ${ }^{83}$ The cultural policies of the 1980s and 1990s, and the central focus on "unity in diversity" in constructions of European identity from the 1970s and intensified in the 1990s, also played to that tune, even if they persisted in the teleology of unity, and often in the assumption of cohesiveness within member-state nations. ${ }^{84}$

Communication and information were key tools in the approximation of the EU and the people, and a clear policy focus. A key motif in the People's Europe imaginary was that of a "dialogue" between the European Community and the European citizens. The latter had not only to be listened to, and to be taken seriously, but they also had to be informed and persuaded. ${ }^{85}$ This meant that communication with the citizens worked in both directions: finding out what they expected from the European level, and which policies and legitimation strategies would appeal to them in their

\footnotetext{
${ }^{80}$ Sternberg, n. 4 Struggle, 119; and Sternberg, n. 4 Trade-Offs.

81 Rosanvallon, n.1 Democratic Legitimacy, 69-70.

82 Sternberg, n. 4 Struggle,145-51.

${ }^{83}$ Rosanvallon, n.1 Democratic Legitimacy, 69-70.

${ }^{84}$ Sternberg, n. 4 Struggle, 145-50.

85 Sternberg, n. 4 Struggle, 82-9.
} 
respective particular situations, but at the same time educating and providing information to them so as to combat what Rosanvallon calls 'feelings of ignorance and loss of control', which 'are in fact a consequence of ignorance'. ${ }^{86}$ The Eurobarometer had been introduced in 1974 to gauge (and construct) European public opinion, in order to inform policy making, but also communication strategies. ${ }^{87}$ Put cynically, the poll importantly scrutinised what people wanted so that they could be told more effectively that they were already getting it. ${ }^{88}$

In discursively managing the EU's much-noted legitimacy crisis following on from the difficult ratification of the Maastricht Treaty in the 1990s, finally, EU-official discourse framed the EU's legitimacy gap to an important degree as an 'information gap', leading to a radical multiplication of efforts and resources dedicated to addressing this gap. ${ }^{89}$ The presumption was: 'the public do not understand European affairs', and better information and communication will 'help it understand' as well as develop positive attitudes towards and a sense of closeness to the EU. ${ }^{90}$ Besides information, Council, Commission, EP, as well as national governments focused their post-Maastricht discursive crisis management on the EU's "democratic deficit", suddenly on everybody's lips. But they effectively and tactically re-defined what democracy might mean in the EU context, diverting attention away from very considerable popular concerns with Economic and Monetary Union and whether democracy was conceivable at all beyond the confines of the nation-state.

The two central pillars of their 'crusade for democracy' were the 'openness' or 'transparency' of EU decision making, on one hand, and the principle of 'subsidiarity' on the other. ${ }^{91}$ Both elements were crucially defined as means of creating proximity. Improving the transparency and openness of the EU's legislative and bureaucratic procedures, the promise was, would bring the EU closer to its citizens and rally lost, and much-needed, popular support. ${ }^{92}$ There were some more specific arguments that it would improve 'public scrutiny' and 'ensure a better informed public debate' on

\footnotetext{
${ }^{86}$ Rosanvallon, n.1 Democratic Legitimacy, 210.

${ }^{87}$ See Bernard Manin, The Principles of Representative Government (Cambridge: Cambridge University Press 1997), 231 on this general point about opinion polls.
}

${ }^{88}$ Rabier, J.-R. (2003). Entretien avec M. Jacques-René Rabier, fondateur de l'Eurobarmomètre, 21 octobre 2003. European University Institute, Oral History Collections, Historical Archives of the European Union, Interview by G. Bossuat, NULL 06/1998; see Sternberg, n. 4 Struggle, 82-9; Claudia Sternberg, 'Public opinion in the EU institutions' discourses on EU legitimacy from the beginnings of integration to today' (2016) 54 Politique européenne, 24-56.

${ }^{89}$ For example, Eurobarometer Nr 38, December 1992:x; see Sternberg, n. 4 Struggle, 129.

90 Walters and Haahr, n. 37, 75; see for example Commission, 'European Governance. A White Paper', COM (2001) 428 final 25 July 2001, 11.

${ }^{91}$ Delors Jacques (1993), 'Address to the European Parliament, 10/02/1993, on the occasion of the investiture debate following appointment of the new Commission', Retrieved 16 September 2020, from http://europa.eu/rapid/ press-release SPEECH-93-8 en.htm?locale=env; see Sternberg, n. 4 Struggle, 128-41.

92 Council. (1992). Conclusions of the European Council Summit in Birmingham (16 October 1992, pp. 407-410). In F. Laursen \& S. Vanhoonacker (Eds., 1994), The Ratification of the Maastricht Treaty: Issues, Debates and Future Implications. Dordrecht: Martinus Nijhoff, 396, 409-10; EP, Reflection Group's Report. A Strategy for Europe (1995). Retrieved from European Parliament, Reflection Group website: http://www.europarl.europa.eu/enlargement/cu/agreements/reflex2 en.htm [accessed 17/07/2019], 4. 
the EU's activities, ${ }^{93}$ in addition to improving the national parliaments' scrutiny of the EU. ${ }^{94}$ Mainly, however, the transparency discourse lay claim to an implied associated sense of 'accessibility, openness, and receptiveness to others' as well as 'an absence of formalism'. ${ }^{95}$ Subsidiarity, in turn, was presented as part of the answer to a widespread popular and political discourse according to which the greater the number of citizens included in the electoral process, the less their individual votes counted. Subsidiarity was to limit on the number of decisions taken at the supranational level, suggesting likewise that decisions would be taken under the citizens' critical gaze, scrutiny and control at lower levels of decision making. ${ }^{96}$ The subsidiarity discourse hence implied a natural link between subsidiarity and transparency - and between both and democratic control and public support. ${ }^{97}$ Indeed, subsidiarity in particular was very often simply equated with 'nearness' or 'closeness' to the citizens. ${ }^{98}$

On the whole, if official EU rhetoric ever since the late 1970s turned on closeness to and openness towards the European citizens in their diverse particular situations, this did not necessarily mean that these citizens got more of an actual say. They remained objects, spectators, and addressees, rather than authors, of EU action. Yes, the citizens and their particular expectations, needs, and sensitivities were at the epicentre of these discourses. But they had a double status: both as an independent source of legitimacy and, at the same time, an object of manipulation. Giving the citizens what they wanted, respectively, in many official discourses pre and post Maastricht, remained a matter of efficient policy-making-only now this was framed in terms of citizen expectations. It was a matter of greater sophistication in mapping, as well as tweaking, particular citizens' expectations: in other words, of bringing them closer to the EU, as much as the EU closer to them.

Reflexivity, the Court of Justice, and EU governance

Rosanvallon's ideal type of reflexive democracy, in turn, is 'democracy's attempt to correct and compensate' flawed assumptions supporting electoral-representative democracy, namely the equation of the voters' choice with the general will, and of the voters, with the people; and that from the moment of the vote flows all subsequent political and legislative activity. Legitimacy in reflexive democracy hence arises from a 'generality of multiplication', which has 'two components: adding complexity to democratic forms on the one hand and regulating the mechanisms of the majoritarian system on the other'. ${ }^{99}$ Reflexive legitimacy arises from multiple representations of the people-who, in the singular is 'unlocatable': the demos or

93 For example, Romano Prodi, 'Speech by Romano Prodi, President of the European Commission to the European Parliament, 14 September 1999'. SPEECH/99/114. Retrieved 16 September 2020 from <http://europa.eu/rapid/press-release_SPEECH-99-114_en.htm<.

94 Council, n. 91, 409; Council, Conclusions of the European Council Summits in Edinburgh (11/12 December 1992, pp. 411-441). In F. Laursen \& S. Vanhoonacker (Eds., 1994), The Ratification of the Maastricht Treaty: Issues, Debates and Future Implications. Dordrecht: Martinus Nijhoff, 412-413.

95 Rosanvallon, n.1 Democratic Legitimacy, 203.

96 For instance, Commission, 'Report on the Operation of the Treaty on European Union (presented by the Commission)' (1995) SEC 95731 final, 10 May 1995.

97 Ibid., 5; Council, n. 91, 410; EP, n. 91, 2.

98 See ibid., 5.

99 Rosanvallon, n.1 Democratic Legitimacy, 123. 
electoral people as it takes on 'numerical reality at the ballot box'; as the social people which can be seen as 'an uninterrupted succession of active or passive minorities'; and as the people as principle, which means bringing to life basic rights, and individual and collective freedom and equality. ${ }^{100}$ Given vocal concerns regarding the existence or, to some, even possibility of a European people as demos, and that the EU's electoral process in itself was insufficient to the EU as a polity, political system, or its policies, efforts to increase EU legitimacy have focused importantly on the latter two expressions of the people.

The importance of the third guise of the people, the 'people as principle', is steadily increasing in the 'new world of singularity' Rosanvallon describes, where the 'rightsbearing subject' is 'the basic figure of this people', and 'the most obvious representation of the idea of a political community'; for, if her 'rights are respected, all voices will be heard'. The people as principle is represented and embodied by constitutional courts, whose primary function as reflexive third parties is 'social and political representation', in addition the regulation of majority rule. ${ }^{101}$ The imaginaries, explored in this volume as a whole, of EU constitutionalism and judicialization of EU politics over time and the role of assumed by the European Court of Justice in shaping integration, including economic and monetary integration, all played on this mode of legitimation. These developments were embedded in the generally increasingly active role of constitutional courts in the member-states, including all of the new Central and Eastern European democracies, whereby judicial review 'has actually supplanted the original doctrine of separation of powers as a way of guaranteeing liberties and regulating majority rule'. ${ }^{102}$

In the EU polity with its challengeable lines of electoral accountability for policy choices, and in the light of recurring critiques (despite all efforts to claim the contrary) that actions and policies at the European level were unresponsive to citizen demands, the judicialization of EU politics and access to the ECJ offered important alternative modes of legitimation, and somewhat satisfied the desire for accountability, increased against this background. ${ }^{103}$ In Rosanvallon's account, constitutional courts provide legitimacy for the political regime as a whole by guaranteeing the promises that a community makes to itself, preserving the identity of democracy and the people over time. ${ }^{104}$ The ECJ in a parallel argument produces legitimacy by interpreting the self-referential, or reflexive, process by which the European demoi have moulded themselves into some kind of whole through expressing their wills. As discussed above, the Commission has joined the Court in assuming this function in its self-declared role as "guardian of the treaties", treating them as the promise made by the Europeans to future generations.

Rosanvallon's second manifestation of generality, the social people, a 'container filled with' all the diverse elements and movements of 'the society', is 'the problematic truth of being together, of its abysses and lies, its promises and unrealized goals'. Representing this people, was the aspiration of "EU governance",

\footnotetext{
100 Rosanvallon, n.1 Democratic Legitimacy, 129-30.

101 Rosanvallon, n.1 Democratic Legitimacy, 123, 131, 140.

102 Rosanvallon, n.1 Democratic Legitimacy, 137.

103 Pierre Rosanvallon, Counter-Democracy: Politics in an Age of Distrust (Cambridge: Cambridge University Press 2008), 191-248.

104 Rosanvallon, n.1 Democratic Legitimacy, 142.
} 
the central paradigm of EU legitimacy of the 1990s formulated in the Commission's 2001 White Paper on European Governance. 105 "Governance" focused attention on the top-down consultation of civil society organisations and organised interests as opposed to individual citizens or "the people". In tune with the spreading perception of society as a configuration of minorities, justifications of this "participatory democracy" included that such consultation would ensure the representation of and fair and equal deliberation among those concerned by the policy in question. ${ }^{106}$ Rosanvallon similarly notes that civil society organisations, social movements, as well as academics 'perform reflexive functions when they denounce discrepancies between the fundamental principles of democracy and the reality' or when they represent future generations, which can be done only 'in the mode of knowledge or concern', essentially by being a factor in present-day discussions. ${ }^{107}$

A multiplication of representation in the sense of being present as a concerns in discussions, was a central trope in legitimations of EU governance and associative or participatory democracy_alongside functional or instrumental arguments about increased policy efficiency and effectiveness due to stakeholder involvement mobilizing buy-in, compliance, as well as expert resources. ${ }^{108}$ The reliance of EU participatory democracy and governance on organised interests was problematic due to its elitist bias, citizen's uneven access to such participation, and the insufficiently democratic internal structures of civil society organizations themselves, all criticisms that in particular the citizen's initiative introduced with the Treaty of Lisbon in 2007 was meant to address. ${ }^{109}$ As for the transparency and openness paradigms, EU governance and participatory democracy positioned the people as 'watchdog', with civil society inspecting, monitoring, investigating, and evaluating the actions of government. ${ }^{110}$ But again, actual influence or accountability was not ensured through electoral accountability, but at best through reputational accountability in the nonliteral sense that policy makers could anticipate to have to justify their decisions to those affected, and would, therefore, feel responsible to them and adapt their actions accordingly. ${ }^{111}$

The EU governance discourse and the related "modes of governance" including "open methods of coordination" was a prime example of official rhetoric seeking to expand the imaginary of political legitimation, and to make democratic forms more complex, while aspiring to modes of legitimation and representation beyond electoral majoritarianism. EU governance has been referred to as the pinnacle of 'procedural depoliticization', on the grounds that those responsible for making a decision are removed from view, obscured by a game of decision-making 'so complex that only experts among the public can keep track of who is playing and where the ball has

\footnotetext{
105 Commission, n. 90.

106 Sternberg, n. 4 Trade-Offs, 624 for references.

107 Rosanvallon, n.1 Democratic Legitimacy, $148 \mathrm{ff}$.

108 See Sternberg, n. 4 Trade-Offs, 624 for source references.

109 Sternberg, n. 4 Trade-Offs, 624.

110 Rosanvallon, n. 76 Counter-Democracy, 13, 29-120.

111 Thomas Risse, 'Transnational governance and legitimacy', in: Arthur Benz \& loannis

Papadopoulos, eds.: Governance and Democracy (London and New YorK: Routledge 2006), 192-212 (192-3); see Sternberg, n. 4 Trade-Offs, 624.
} 
got to'. ${ }^{112}$ Further, governance prioritised responsiveness to citizen expectations over democratic control, representation, or accountability, as had the People's Europe complex and even the advocacy of EP elections before. Although all these discourses highlighted the need for the visibility, understandability, and transparency of government, they ultimately rated such responsiveness as the even higher aim. ${ }^{113}$ Much of "EU governance" plugged into discourses of proximity, transparency and closeness to the citizens (and the paradigm could have been included above in the section on proximity).

EU governance explicitly aspired to a new type of democracy, superior to the classic majoritarian, electoral, and particularly, the parliamentary models of democracy, all of which suffered from a 'growing crisis of faith' and 'disenchantment', ${ }^{114}$ and had led to the citizens' 'alienation from politics'. ${ }^{115}$ Governance by contrast claimed to embody the 'kind of democracy our fellow-citizens want': 116 a more "genuine" type of democracy that was 'much more participatory, "hands-on"' 117 —even though in effect, governance and 'participation' were not about majoritarian representation, 'not about institutionalising protest', but 'about more effective policy shaping'. ${ }^{118}$

Impartiality

The legitimacy of impartiality, finally, in Rosanvallon's ideal type is associated with independent authorities of surveillance and regulation, central banks being a classic example. This type of legitimacy is grounded in 'negative generality', or a 'detachment from particularities'. An impartial authority is structurally independent, but it also behaves in a certain way; maintaining an equilibrium and 'a rational and organized distance from the different aspects of a question' as well as 'adopting all conceivable points of view'.

The mode of legitimation, again, is grounded in an apprehension of "the people" not in an electoral perspective. It rests on an understanding of 'democracy as the power of everybody' not in the 'arithmetic and aggregative' sense expressed in universal suffrage. Rather, such a political subject is apprehended socially, 'coming from a capacity to take into account everybody's problems'. ${ }^{119}$ This way of understanding "the people" closely resonates with the explicit self-understanding of the Commission, refreshed in its governance paradigm, as guardian of the common European interest, and 'sympathetic ear' and impartial mediator between a

\footnotetext{
112 Van Middelaar, n.49, 242.

113 See Sternberg, n. 4 Struggle, 55, 75, 84, 101, 190,

114 Romano Prodi, 'Speech to the European Parliament on 04 September 2001. "The European Union and its Citizens: a Matter of Democracy"', SPEECH/01/365. Retrieved 16 September 2020 from https://ec.europa.eu/commission/presscorner/detail/en/SPEECH_01_365.

115 Commission, n. 90, 32.

116 Prodi, n. 113.

117 Romano Prodi, 'Speech to the European Parliament on 15 February 2000. "Shaping the New Europe"'. SPEECH/00/41, Retrieved 16 September 2020 from https://ec.europa.eu/commission/presscorner/detail/en/SPEECH_00_41.

118 Commission, n. 90, 14-15.

${ }^{119}$ Rosanvallon, n.1 Metamorphoses, 117, 119; see n.1 Democratic Legitimacy, 89, 07 and 73-120.
} 
contrasting political views, national interests, and interest group pressures, as well as the centre of technocratic expertise. ${ }^{120}$

Furthermore, alongside the European Central Bank (ECB), there exist now over 40 independent agencies of the $\mathrm{EU}$, who regulate, consult, or facilitate dialogue in such politically sensitive areas as migration, medicines, food safety, and so on. Endowed 'with powers of variably scope', they all 'derive their political authority essentially from their technical expertise and their status as independent instances'. ${ }^{121}$ Especially in the past two decades, a growing number of decentralized agencies have been established and given increasingly significant powers, in contrast to the modest powers granted to the earlier agencies. ${ }^{122}$ 'Sweeping competences have been delegated' not least in the context of the Euro crisis, as for the troika, the European Stability Mechanism, or ECB banking supervision. ${ }^{123}$ This 'agencification of the EU administration' has been described as 'hardly controlled', given the lack of clear criteria, or a sound legal basis or framework as to when and how recourse to the agency instrument may be justified in either the Treaties or secondary law. ${ }^{124}$ The mandates of some of these bodies have become extremely politically salient, whether owing to practical need as for the question of Frontex's role in rescue at sea, 'practical overreach' as in implementing the reception or distribution of asylum seekers across member-states in the autumn of $2015,{ }^{125}$ or the respective body's creative interpretation of their mandate. The ECB's mandate for instance, "defence of price stability", 'may seem very narrow and technical but in the wake of intense interpretative work carried out by the ECB, this mandate has enabled the bank to take action in areas ranging from pensions, wage policies and labour law to State organization, and more'. 126

In Rosanvallon's book, independent administrative authorities proliferated in response to demands for regulation where existing bureaucratic structures had run into difficulty owing to technical complexity, overlapping competences, a multiplication of affected parties and/or a diffusion of responsibilities. ${ }^{127}$ As an earlier advocate of "autogestion" and fervent critic of bureaucracy within both the civil service and parties during the 1970s, Rosanvallon is careful to differentiate the impartial institutions he promotes from "bureaucracy", suggesting that bureaucracy runs an inherent risk of becoming "ossified", "mechanised", its rules and procedures automatic and difficult to change even when proving ineffective. ${ }^{128}$ The proliferation of independent regulatory authorities across the world, by contrast, he presents as

\footnotetext{
120 Myrto Tsakatika, 'Claims to Legitimacy: The European Commission between Continuity and Change' (2005) JCMS 43, 193-220 (199-200); see Sternberg, n. 4 Struggle, 145 for source references.

121 Antoine Vauchez, Democratizing Europe (Basingstoke: Palgrave Pivot, 2015), 40.

122 Merijn Chamon. EU Agencies: Legal and Political Limits to the Transformation of the EU Administration (Oxford: Oxford University Press 2016).

123 Vauchez, n. 121, 3.

124 Chamon, n. 121.

125 Van Middelaar, n.49, 94-101.

126 Vauchez, n. 121, 71.

127 Rosanvallon, n.1 Democratic Legitimacy, 80.

128 Hudson, n. 16, 157, 174; Rosanvallon, n.1 Democratic Legitimacy, 97.
} 
reflecting 'new social expectations', and people wanting 'a more open and interactive process of policy making' with 'more input from conflicting points of view'. The '"technical" requirements of certain types of regulation' thus combined with "'democratic" aspirations for more public justification of policy decisions, greater openness, and above all, greater impartiality' to foster the emergence of independent agencies across modern democracies. ${ }^{129}$

In contrast to the promises of the ideal type of impartial independent agencies, however, the agencification of the EU was in effect a way of allowing less, rather than more, democracy. For it worked to shield certain policy areas from electoral and public accountability and scrutiny as well as from direct Commission influence, while still allowing for administrative co-ordination and co-operation and EU-level capacity building. ${ }^{130}$ Notwithstanding, there is a close resemblance between Rosanvallon's ideal type of impartial independent authorities, and in particular the aspiration to greater openness and interactive elements with closely corresponding tropes in the EU governance and participatory democracy discourses. The ECB for one, furthermore, adopted these arguments and aspirations around the legitimacy of impartial authorities to the dot. During the financial crisis, the bank intensified its 'accountability practices' in response to 'public demand for increased scrutiny'. It staked out accountability as the 'crucial cornerstone' of its legitimacy as a "very powerful and independent yet unelected"' body, and as crucial in building the trust among the European citizens that was indispensable to its fulfilling its mandate. What it defined central bank accountability was 'the legal and political obligation of an independent central bank to explain and justify its decisions to citizens and their elected representatives'. ${ }^{131}$ Again, this is accountability mainly of the reputational kind referred to above, of power-holders ideally adapting their choices and policies with a view to how they could present them to their constituencies. ${ }^{132}$ Crucially, the ECB's impartiality could not be enforced beyond its treaty mandate; the citizens had to take its word for it, and trust that it would take all of their viewpoints into account in making its decisions. In the end of the day, however, especially those on the losing end were not always convinced that their interests had been given the adequate weight. ${ }^{133}$

In reality, Rosanvallon's impartiality-based legitimacy may on the whole be closer to bureaucratic legitimacy than he concedes. For one, bureaucracy itself has adapted, and often become more flexible and decentralised, embracing openness, transparency, and public reason-giving. ${ }^{134}$ As developed in the previous sections,

\footnotetext{
129 All Rosanvallon, n.1 Democratic Legitimacy, 82.

130 Chamon, n. 121, Chapter III.

131 All ECB, 'The evolution of the ECB's accountability practices during the crisis', prepared by Niccolò Fraccaroli, Alessandro Giovannini and Jean-François Jamet. (2018) ECB Economic Bulletin (5). https://www.ecb.europa.eu/pub/economic-

bulletin/articles/2018/html/ecb.ebart201805_01.en.html\#toc1 [accessed 17/07/2019], citing Draghi for the double inverted commas, emphasis added. Specifically, the ECB here highlighted its deepened interactions with the EP, as well as its 'network of interactions with institutions such as the European Ombudsman, the European Court of Auditors (ECA), the European Anti-Fraud Office and the European Data Protection Supervisor'.

132 See also David Beetham, The legitimation of power (Basingstoke: Macmillan, 2013), 9, 19, 258.

133 Sternberg et al., n. 5 Mutual Recognition.

134 Hudson, n. 16, 156.
} 
the European Commission is a paradigm case of a bureaucratic institutions adapting to changes in the discursive landscape of what might plausibly pass as conferring legitimacy, and espousing many constitutive elements of the impartiality as well as proximity and reflexivity modes of legitimation. Moreover, both impartiality and independence are likely to rate highly in the professional self-understanding and ethic of many bureaucrats, from the top down to the bottom ranks, with Commissioners for example to this day taking an oath of independence, from national or private interests and from political-ideological bias on appointment. ${ }^{135}$ Most importantly, however, impartiality as a mode of legitimation continues to rely on claims to technical expertise and skills, and to universality and objectivity 'in order to produce results and promote consensus and social change'-all of which one might define as the essence of 'bureaucratic thinking'. ${ }^{136}$ In practice, as Rosanvallon notes, independent agencies, just like bureaucratic bodies, can be "captured" by interest groups or manipulated by politicians and bureaucrats'. ${ }^{137}$

This, too, is to do not least with these bodies' 'claim to scientific objectivity in their analysis' and the underlying doctrines, models, methodologies, and instrumentswhich effectively obscures values and interests behind policy decisions that are presented as neutral, technical, and fact-based. Examples are the new public management theories used by the Commission since the 1990s to legitimise the setting up of agencies discussed above, or the economic theories on which the troika based its austerity policies in Greece and Portugal. ${ }^{138}$ The policies of the troika, and the fierce public and political reactions to them, brought to the limelight, further, that the policy decisions taken on these supposedly objective and impartial grounds were a far cry from being neutral, but rather created winners and losers in the most acutely felt and vocally admonished ways. ${ }^{139}$ The same applied to central bank independence as well as to the EU and Economic and Monetary Union's own brand of economic constitutionalism-object of prominent critiques of the EU. ${ }^{140}$

Rosanvallon recognises this danger, giving economic constitutionalism as an illustration of the need for complementing impartiality as a mode of legitimation and governance with reflexivity. ${ }^{141}$ Elements of proximity, in turn, are crucial in his delineation of impartiality from bureaucracy's orientation towards generality. Impartiality hence is embedded in the other two ideal types of his alternative modes of democratic legitimacy, as they are all mutually intertwined.

\section{Unpolitical democracy?}

What about partisan electoral democracy, however? Has Rosanvallon 'given up' on its reactivation, ${ }^{142}$ and is this a reason why his analyses chime so well with many discourses and supporting practices around the legitimacy of a polity that, despite all

\footnotetext{
135 Tsakatika, n. 120, 199-200.

136 Hudson, n. 16, 4-5.

137 Rosanvallon, n.1 Democratic Legitimacy, 99.

138 Vauchez, n. 121, 40, 71, 74-5.

139 Sternberg et al., n. 5 Mutual Recognition.

140 See Christian Joerges' chapter in this volume.

141 Rosanvallon, n.1 Democratic Legitimacy, 150-3.

142 Hudson, n. 16, 155.
} 
attempts to redeem this, continues to struggle to build an electoral party politics that can go further than the current setup in providing legitimacy for the EU and its policies?

The gravest critique of Democratic Legitimacy ${ }^{143}$ and Counter-Democracy ${ }^{144}$ is that Rosanvallon in them falls for the appeal of 'unpolitical democracy'. ${ }^{145}$ On the basis of his critique of party democracy, ${ }^{146}$ Democratic Legitimacy has been used as the exemplary text of 'the contemporary case for technocracy'. By emphasising the indirect institutions of impartiality, reflexivity, and proximity, Rosanvallon arguably presents an account that at best distracts from the role of majoritarian elections 'as part of a broader process through which an overarching conception of the "common good' is progressively extrapolated and defined out of the plurality of particular interests present within society'. It distracts, further, from the role of political parties in reflecting social divisions or constituting them politically into competing visions of the common good. ${ }^{147}$

Rosanvallon does recognise unpolitical democracy as an 'omnipresent threat'. ${ }^{148}$ Yet, in his effort to contain the threat of populism, he arguably opts against reinstating electoral politics as a central source of democratic legitimacy. Rather, he seeks to politicise the spheres of indirect democracy, defending his modes of legitimacy and institutions of indirect democracy, of proximity, reflexivity, and impartiality, as essentially political. Antoine Vauchez has developed this proposition by elaborating how the academic community or the interlocutors of the CJEU, the ECB and the Commission, including lawyers, consultants, experts, activists can take up arms against and mobilise criticism against the de-politicising 'pretence to scientific objectivity' of their judgments and policy choices, by breaking open 'the black box of doctrines, methodologies and instruments' and scrutinizing the data, facts, arguments, 'and ultimately the decisions put forward by these institutions'. ${ }^{149}$ Even in the fields of technocratic, impartial and reflexive politics, forms of opposition are thus conceivable, ${ }^{150}$ although their indirect institutions have been blamed for encouraging passivity among the citizens. ${ }^{151}$ Nevertheless, in the absence of a (re-)activation of partisan politics, looking for "the political" in the indirect institutions of particularity, reflexivity, and impartiality has been judged as a 'strategic use of

\footnotetext{
143 Rosanvallon, n.1 Democratic Legitimacy.

144 Rosanvallon, n. 76 Counter-Democracy.

145 Nadia Urbinati, 'Unpolitical Democracy' (2010) Political Theory 38(1), 65-92.

146 For example, in the context of discussing the factors that led to the formation of independent bureaucracies as ways of compensating for the inherent deficiencies of electoral democracy, he writes that 'political parties were not instruments for representing the public interest, but for enabling private interests to capture the public sphere' (Rosanvallon, n.1 Democratic Legitimacy, 37).

147 Christopher Bickerton \& Carlo Invernizzi Accetti, 'Populism and technocracy: opposites or complements?' (2017) Critical Review of International Social and Political Philosophy 20(2), 186-206 $(188,198)$; see Jonathan White \& Lea Ypi, 'Rethinking the Modern Prince: Partisanship and the Democratic Ethos', (2010) Political Studies 58, 809-828 (816).

148 Rosanvallon, n.1 Democratic Legitimacy, 222.

149 Vauchez, n. 121, 74-5.

150 Van Middelaar, n. 49, 241.

151 Hudson, n. 16, 3.
} 
deliberation as an antidote against democratic procedures themselves (like voting and majority rule)'. ${ }^{152}$

This reading rejects as lip service, in effect, Rosanvallon's commitment that democracy 'must make room for both conflict and consensus'; that it must both restore 'the clash of platforms and values' or the partisan divisions of majoritarian democracy 'to a position of respect', and acknowledge the role of independent agencies, constitutional courts, and other authorities and the 'value' of their 'more unanimous decisions'. ${ }^{153}$ Party politics, Rosanvallon vows, is 'absolutely essential and entirely legitimate' where choices are to be made, options to be selected and conflicting interests and judgments to be reconciled. Impartiality, by contrast, is essential in guaranteeing and approaching equality, as well as 'when dealing with basic aspects of the social contract (as opposed to the "majoritarian contract")'. The difficult question, however, 'at the heart of democratic life', is where to draw the line 'between majoritarian politics and the politics of impartiality'. The example that Rosanvallon gives is monetary policy, which in Germany is part of this basic social contract for historical reasons, whereas in other countries it is properly a matter of partisan politics. ${ }^{154}$ It is also an example of the need for partisan politics in assigning the policy to the appropriate mode of legitimation. European monetary policy, as the handling of the euro crisis, are examples of decisions of utmost political and social consequence being partly usurped into a zone operating under claims to technical objectivity, independence, and impartiality, as well as possible to particularity and reflexivity (the German Constitutional Court after all got its say)—when in many member-states, including those most painfully affected, it was partisan politicisation and electoral procedures that were vocally demanded. ${ }^{155}$

\section{Conclusion}

In conclusion, the juxtaposition of Rosanvallon's trajectory of the crisis and recovery of democratic legitimacy through new avenues to my discourse-historical narrative of shifting EU-official constructions of EU legitimacy has pointed to some important differences, in particular in the balance between electoral and bureaucratic legitimacy in the earlier years of integration. It has also found abundant similarities and interaction. The legitimation challenges specific to the EU constellation seem to have made it a particularly suitable playing field for the experimentation with alternative modes of legitimation of the types that Rosanvallon discusses, which do at times almost read like a play book for EU-official legitimation paradigms and public relation campaigns.

Furthermore, the ways in which Rosanvallon's modes of legitimation have played out in the EU context point to dangers inherent to them, individually and as a whole: of highlighting openness, transparency, and closeness (proximity) over actual influence and control (People's Europe, 1980s); of making democratic forms so complex (reflexive) that they become unintelligible and hence unaccountable; of emphasising participatory democracy as in the top-down consultation of civil society organisations and organised interests over party democracy and the electoral representation of

\footnotetext{
152 Urbinati, n. 130, 65.

153 Rosanvallon, n.1 Democratic Legitimacy, 224.

154 Rosanvallon, n.1 Democratic Legitimacy, 215, 119.

155 Sternberg et al., n. 5 Mutual Recognition.
} 
individual citizens (EU governance, 2000s), or replicating bureaucratic logics that work to obscure choices and judgments behind claims to objectivity, independence, and impartiality. Taken together, Rosanvallon's account and developments in the EU's discursive history of legitimation, risk falling for the temptation of unpolitical democracy rather than containing its threat; especially in claiming to politicise the indirect institutions of impartiality, reflexivity and proximity, deliberation risks being used strategically as an antidote against democratic procedures of voting and majority rule.

\section{References}

Beetham, David. 2013. The legitimation of power. Basingstoke: Macmillan.

Bickerton C., Accetti C.I., Bickerton C., \& Accetti C.I. (2017). Populism and technocracy: opposites or complements? Critical Review of International Social and Political Philosophy, 20(2), 186-206.

Burgess, M. (1989). Federalism and European Union: Political Ideas, Influences, and Strategies in the European community, 1972-1987. London; New York: Routledge.

Burgess, M. 2000. Federalism and European Union: The Building of Europe, 19502000, London, Routledge.

Commission. (1961a). Fourth General Report on the Activities of the Community (16 May 1960 - 30 April 1961). http://aei.pitt.edu/30807/ [accessed 17/07/2019].

Commission. (1972). Report of the Working Party Examining the Problem of the Enlargement of the Powers of the European Parliament. 'Vedel Report'. Bulletin of the European Communities, Supplement 4(72).

Commission. (1985). Reports from the Ad Hoc Committee on a People's Europe, Brussels, chaired by Pietro Adonnino, 25 and 26 June 1985, and 29 and 30 March 1985. Bulletin of the European Economic Community, Supplement 7/85, 2-33.

Commission. (1988a). A People's Europe. Communication from the Commission to the European Parliament (7 July 1988). COM 88 331/final. Bulletin of the European Communities, Supplement 2.

Commission. (1995). Report on the Operation of the Treaty on European Union.

Commission. (2001). European Governance. A White Paper (25 July 2001). $\operatorname{COM}(2001) 428$ final.

Commission. (2006). White Paper on a European Communication Policy, COM(2006) 35 final, (01/02/2006). Brussels: Commission of the European Communities.

Chamon, M. (2016). EU Agencies: Legal and Political Limits to the Transformation of the EU Administration. Oxford: Oxford University Press.

Conway, M., \& Depkat, V. (2010). Towards a European History of the Discourse of Democracy: Discussing Democracy in Western Europe 1945-60. In M. Conway \& K. K. Patel (Eds.), Europeanization in the Twentieth Century: Historical Approaches (pp. 132-156). Basingstoke and New York: Palgrave Macmillan.

Conway, M., \& Romijn, P. (2004). Introduction to Theme Issue: Political Legitimacy in Mid-Twentieth Century Europe. Contemporary European History, 13, 377-388. 
Council. (1984). Conclusions of the Fontainebleau European Council (25 and 26 June 1984). Bulletin of the European Communities, June 1984, 11-12.

Council. (1992). Conclusions of the European Council Summits in Lisbon (26/27 June 1992, pp. 393-406), Birmingham (16 October 1992, pp. 407-410), Edinburgh (11/12 December 1992, pp. 411-441). In F. Laursen \& S. Vanhoonacker (Eds., 1994), The Ratification of the Maastricht Treaty: Issues, Debates and Future Implications. Dordrecht: Martinus Nijhoff.

de Gaulle, C. Press conference 09/09/1965. http://aei.pitt.edu/5356/ [accessed 17/07/2019].

Draghi, M. (2014, August 4). Central Bank Communication. Handelsblatt. https://www.ecb.europa.eu/press/inter/date/2014/html/sp140804.en.html [accessed 17/07/2019].

ECB. (2018). The evolution of the ECB's accountability practices during the crisis. Prepared by Nicolò Fraccaroli, Alessandro Giovannini and Jean-François Jamet. ECB Economic Bulletin, (5). https://www.ecb.europa.eu/pub/economicbulletin/articles/2018/html/ecb.ebart201805_01.en.html\#toc1 [accessed 17/07/2019].

EP. (1995). Reflection Group's Report. A Strategy for Europe. Retrieved from European Parliament, Reflection Group website:

http://www.europarl.europa.eu/enlargement/cu/agreements/reflex2 en.htm [accessed 17/07/2019].

EPA. (1960). Rapport fait au nom la commission des affairs politiques et des questions institutionnelles sur l'élection de l'Assemblée parlementaire européenne au suffrage universel direct. EP Session Documents 1960-61, 30 April 1960, Document 22.

Ezrahi, Y. (2012). Imagined Democracies: Necessary Political Fictions. Cambridge: Cambridge University Press.

Featherstone, K. (1994). Jean Monnet and the 'Democratic Deficit' in the European Union. Journal of Common Market Studies, 32, 149-170.

Freeden, M. (1998). Ideologies and Political Theory: A Conceptual Approach, Oxford, OUP.

Freeden, M. (2004). Ideology, Political Theory and Political Philosophy. In Handbook of Political Theory (pp. 3-17), London: Sage.

Haas, E. (1968). Technocracy, Pluralism and the New Europe. In J. Nye (Ed.), International Regionalism. Boston, MA: Little Brown.

Habermas, J. (1973). Legitimation Crisis. Boston: Beacon.

Hall, P. A. (1989). The Political Power of Economic Ideas: Keynesianism across Nations. Princeton, NJ: Princeton University Press.

Hansen, L., \& Williams, M. C. (1999). The Myths of Europe: Legitimacy, Community and the 'Crisis' of the EU. Journal of Common Market Studies, 37, 233-249.

Held, D. (2006). Models of Democracy. Stanford: Stanford University Press.

Hudson, J. M. (2016). The Bureaucratic Mentality in Democratic Theory and Contemporary Democracy (Columbia University, PhD Thesis). 
Jacques Delors. (1993). Address to the European Parliament. Bulletin of the European Communities, Supplement 1/93. http://aei.pitt.edu/30732/ [accessed 17/07/2019]

Kelsen, H., Urbinati, N., \& Accetti, C. I. (2013). The essence and value of democracy. Lanham: Rowman \& Littlefield Publishers, Inc.

Lindseth, P. L. (2010). Power and Legitimacy: Reconciling Europe and the NationState. Oxford University Press.

Mair, P., \& Thomassen, J. (2010). Political Representation and Government in the European Union. Journal of European Public Policy, 17, 20-35.

Majone, G. (1996). Regulating Europe. London: Routledge.

Majone, G. (1998). Europe's Democratic Deficit: The Question of Standards. European Law Journal, 4, 5-28.

Manin, B. (1997). The Principles of Representative Government. Cambridge: Cambridge University Press.

Middelaar, L. van. (2019). Alarums and excursions. Newcastle: Agenda Publishing. Müller, J.-W. (2013). Contesting democracy: Political ideas in twentieth-century Europe. New Haven: Yale University Press.

Prodi, R. (1999), 'Speech by Romano Prodi, President of the European Commission to the European Parliament, 14 September'. SPEECH/99/114. Retrieved 16 September 2020 from <http://europa.eu/rapid/press-release_SPEECH-99114 en.htm<.

Prodi, R. (2000), 'Speech to the European Parliament on 15 February 2000. "Shaping the New Europe"'. SPEECH/00/41, Retrieved 16 September 2020 from https://ec.europa.eu/commission/presscorner/detail/en/SPEECH_00_41.

Prodi, R. (2001). Speech to the European Parliament on 04/09/2001. 'The European Union and its Citizens: a Matter of Democracy'. http://europa.eu/rapid/pressrelease SPEECH-01-365 en.htm?locale=en [accessed 17/07/2019]/

Rabier, J.-R. (2003). Entretien avec M. Jacques-René Rabier, fondateur de I'Eurobarmomètre, 21 octobre 2003. European University Institute, Oral History Collections, Historical Archives of the European Union, Interview by G. Bossuat, NULL 06/1998.

Risse, T. 'Transnational governance and legitimacy', in: Arthur Benz \& loannis Papadopoulos, eds.: Governance and Democracy (London and New YorK: Routledge 2006), 192-212

Rosanvallon, P. (2006) [2001]. The Transformation of Democracy and the Future of Europe. In: S. Moyn (Ed.), Democracy Past and Future. New York: Columbia University Press, 218-34.

Rosanvallon, P. (2008). Counter-Democracy: Politics in an Age of Distrust. Cambridge: Cambridge University Press.

Rosanvallon, P. (2011a). Democratic Legitimacy: Impartiality, Reflexivity, Proximity. Princeton: Princeton University Press.

Rosanvallon, P. (2011b). The Metamorphoses of Democratic Legitimacy: Impartiality, Reflexivity, Proximity. Constellations, 18(2), 114-123. 
Shore, C. (2000). Building Europe. The Cultural Politics of European Integration. London: Routledge.

Sternberg, C. S. (2013). The Struggle for EU Legitimacy: Public Contestation, 19502005. Basingstoke: Palgrave.

Sternberg, C. S. (2015). Political legitimacy between democracy and effectiveness: Trade-offs, interdependencies, and discursive constructions by the EU institutions. European Political Science Review, 7(04), 615-638.

Sternberg, C. (2016). Public opinion in the EU institutions' discourses on EU legitimacy from the beginnings of integration to today, Politique européenne, 54, 2456.

Sternberg, C. (forthcoming). 'Democracy Narratives', in Mathieu Segers et al., eds., The Cambridge History of the European Union (Cambridge: Cambridge University Press).

Sternberg, C., Gartzou-Katsouyanni, K., \& Nicolaidis, K. (2018). The Greco-German Affair in the Euro Crisis. London: Palgrave Pivot.

Taylor, C. (2003). Modern Social Imaginaries. Durham, NC: Duke University Press.

Thompson, J. B. (1994). Ideology and modern culture: Critical social theory in the era of mass communication. Cambridge: Polity Press.

Tsakatika, M. (2005). Claims to Legitimacy: The European Commission between Continuity and Change. Journal of Common Market Studies, 43, 193-220.

Urbinati, N. 'Unpolitical Democracy' (2010) Political Theory 38(1), 65-92.

Vauchez, A. (2015). Democratizing Europe. Basingstoke: Palgrave Pivot.

Walters, W., \& Haahr, J. H. (2005). Governing Europe. Discourse, governmentality and European integration. London and New York: Routledge.

White, J., \& Ypi, L. (2010). Rethinking the Modern Prince: Partisanship and the Democratic Ethos. Political Studies, 58, 809-828.

Yanow, D., \& Schwartz-Shea, P. (2006). Interpretation and Method. Empirical Research Methods and the Interpretive Turn. Armonk, N.Y.: M.E. Sharpe. 
Author(s): Claudia Sternberg

Title: Ideologies and imaginaries of legitimacy from the 1950s to today: trajectories of EU-Official discourses read against Rosanvallon's Democratic Legitimacy

iCourts Working Paper Series, No. 230, 2021

Publication date: 7/January/2021

URL: http://jura.ku.dk/icourts/working-papers/

(C) Author

iCourts Working Paper Series

ISSN: 2246-4891

Claudia Sternberg, Principal Research Fellow at the UCL European Institute

E-mail: c.sternberg@ucl.ac.uk

The iCourts Online Working Paper Series publishes pre-print manuscripts on international courts, their role in a globalising legal order, and their impact on politics and society and takes an explicit interdisciplinary perspective.

Papers are available at http://jura.ku.dk/icourts/

iCourts

- The Danish National Research Foundation's Centre of Excellence for International Courts The Faculty of Law University of Copenhagen

Karen Blixens Plads 16

2300 Copenhagen $S$

E-mail: icourts@jur.ku.dk

Tel. +4535322626 